Journal of Indonesian Tourism, Hospitality and Recreation --- Volume 2, No. 1, April 2019

eISSN: 2654-4687 ----- pISSN: 2654-3893

\title{
KAJIAN PENGEMBANGAN AGRIBISNIS SINGKONG (Manihot esculenta) BERBASIS KEARIFAN LOKAL MELALUI PENERAPAN AGROWISATA DI KAMPUNG CIREUNDEU
}

Euis Dasipah ${ }^{(1)}$, I. Iskandar ${ }^{(2)}$, Rimelke R. Febryane ${ }^{(3)}$

euisdasipah@gmail.com, bpkiisiskandar@yahoo.co.id

(1)(3) Universitas Winaya Mukti

(2) Universitas Bina Sarana Informatika Bandung

\begin{abstract}
ABSTRAK
Kampung Adat Cireundeu merupakan salah satu wilayah industri Kota Cimahi yang masih mempertahankan kegiatan pertanian. Keunggulan daerah (comparative advantage) yang dimiliki meningkatkan potensi Kampung Adat Cireundeu mengembangkan agribisnis singkong melalui penerapan agroindustri dan agrowisata berbasis kearifan lokal. Jumlah pengunjung yang masih sedikit dan fluktuatif akan menentukan jumlah permintaan produk agroindustri singkong karena sebagian besar konsumen merupakan pengunjung Kampung Adat Cireundeu. Tujuan penelitian ini adalah mengetahui adanya keterkaitan antara agroindustri singkong dan agrowisata di Kampung Adat Cireundeu, dan mengetahui strategi yang tepat untuk pengembangan agribisnis di Kampung Adat Cireundeu berbasis kearifan lokal. Metode yang digunakan adalah studi kasus dengan melakukan analisis deskriptif kualitatif pada 37 responden dengan alat analisis yang terdiri dari persepsi pengunjung, WTP, IFE, EFE, dan SWOT. Hasil dari penelitian ini menunjukkan bahwa adanya keterkaitan antara agroindustri singkong dan agrowisata di Kampung Adat Cireundeu dengan posisi strategi pada kuadran 3 sehingga Kampung Adat Cireundeu perlu melakukan diversifikasi strategi. Strategi yang tepat untuk pengembangan agribisnis singkong di Kampung Adat Cireundeu berbasis kearifan lokal, yaitu 1) Memperkenalkan produk melalui media berupa brosur yang diberikan kepada konsumen yang pernah datang, 2) Mendirikan restoran yang bernuansa Kampung Adat Cireundeu, dan 3) Memperbanyak saluran pemasaran agar jaringan hubungan konsumen semakin luas.
\end{abstract}

Kata kunci: Agroindustri, Agrowisata, Analisis Persepsi Pengunjung, WTP, dan SWOT.

\section{STUDY OF LOCAL WISDOM-BASED CASSAVA (Manihot esculenta) AGRIBUSINESS DEVELOPMENT THROUGH THE APLLICATION OF AGRO- TOURISM IN THE CIREUNDEU VILLAGE}

\section{ABSTRACT}

Kampung Adat Cireundeu is one of areas an industrial Cimahi City who maintain the agricultural sector. Primary area (comparative advantage) owned increase potential Kampung Adat Cireundeu agribusiness develop of cassava with the application of agroindustry and agrotourism based on local cultural. The number of visitors still a little and fluctuates will determine the number of requests products agroindustry because most consumers is visitors of Kampung Adat Cireundeu. The purpose of research is to know the linkages between agroindustry and agrowisata in Kampung Adat Cireundeu and know strategy proper to the development of agribusiness in Kampung Adat Cireundeu based on local cultural. Methods used is the case study by doing descriptive qualitative analysis in 37 respondents with a analysis of perception visitors, WTP, IFE, EFE, and SWOT. The result of the research indicated that the existence of the links between agroindustry and agrotourism in Kampung Adat Cireundeu with the position of strategy at the quadrant 3 that Kampung 
Euis Dasipah, I. Iskandar, dan Rimelke R. Febryane: Kajian Pengembangan Agribisnis Singkong (Manihot Esculenta) Berbasis Kearifan Lokal Melalui Penerapan Agrowisata Di Kampung Cireundeu

Adat Cireundeu need diversified strategy. The right strategy to the development agribusiness of cassava in Kampung Adat Cireundeu based on local wisdom, such as 1) Introducing products through the medium of in the form of a leaflet given to consumers that never came, 2 ) Created a restaurant Kampung Adat Cireundeu's nuance, and 3 ) Make many marketing line so the consumer relations the larger.

Keywords: Agroindustry, Agrotourism, Analysis Of Percepstion Visitors, WTP, and SWOT.

\section{PENDAHULUAN}

Negara Indonesia merupakan negara yang sebagian besar penduduknya berprofesi di sektor pertanian karena Indonesia adalah negara Agraris. Sektor pertanian menjadi sektor yang sangat dominan dan berperan sebagai tulang punggung perekonomian Indonesia. Luas lahan dan kekayaan alam yang dimiliki Indonesia merupakan modal utama dalam mengembangkan sektor pertanian secara intensif dan terencana melalui sistem agribisnis. Kebutuhan akan pengembangan agribisnis telah berkembang saat ini, khususnya Indonesia yang memiliki potensi sumber daya alam yang sangat besar untuk menjalankan berbagai kegiatan agribisnis. Agribisnis adalah usaha di bidang pertanian yang terdiri atas beberapa subsistem dari sektor hulu hingga hilir yang kegiatannya meliputi produksi, pengolahan hasil/penambahan nilai produk, dan pemasaran (Sjarkowi dan Sufri, 2004). Dengan adanya kegiatan agribisnis banyak hal yang dapat diwujudkan salah satunya kedaulatan pangan yang sedang menjadi isu paling gencar diberbagai wilayah.

Kedaulatan pangan adalah konsep pemenuhan pangan melalui produksi lokal yang berkualitas gizi baik dan sesuai secara budaya, diproduksi dengan sistem pertanian yang berkelanjutan dan ramah lingkungan. Kedaulatan pangan merupakan hak setiap bangsa dan setiap rakyat untuk memproduksi pangan secara mandiri dan hak untuk menetapkan sistem pertanian, peternakan, dan perikanan tanpa adanya subordinasi dari kekuatan pasar Internasional (Serikat Petani Indonesia).
Kenyataannya, kedaulatan pangan masih sulit dicapai hingga perlu mengimpor beras karena tingginya tingkat konsumsi beras.

$$
\text { Konsumsi Beras Perkapita Indonesia 2011-2015 }
$$

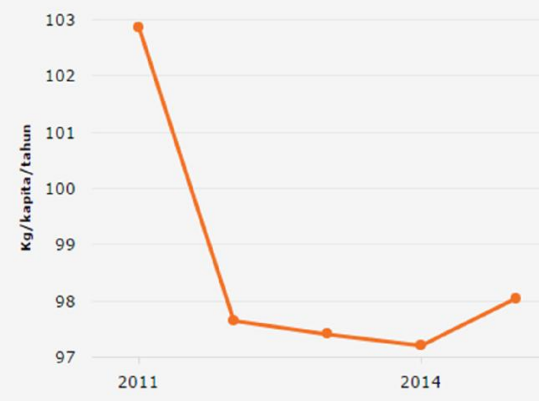

Sumber: databoks.katadata.com (2016)

Gambar 1. Grafik Tingkat Konsumsi Beras Tahun 2011-2015

Untuk mencapai kedaulatan pangan yang diharapkan maka diperlukan perubahan pola konsumsi pangan Indonesia baik dengan cara subtitusi maupun diversifikasi pola konsumsi. Perubahan pola konsumsi secara diversifikasi dengan cara melakukan variasi pada konsumsi bahan makanan pokok seperti, roti, kentang, jagung dan lain-lain yang dikonsumsi pada pagi hari, ataupun dengan mengikuti program "one day no rice", dan sebagainya. Adapun cara subtitusi yaitu, mengganti pola konsumsi makanan pokok dari beras menjadi yang lain, salah satu contohnya singkong.

Singkong (Manihot esculenta) adalah pohon tahunan tropika dan subtropika dari keluarga Euphorbiaceae. Umbinya dikenal sebagai makanan pokok penghasil karbohidrat dan cocok menjadi pengganti beras mengingat tingkat konsumsi beras di 
Indonesia yang tinggi dan kandungan nutrisinya tidak jauh berbeda serta dapat dilihat pada Tabel 1, dimana singkong yang diteliti sebanyak 100 gr dan singkong yang dapat dikonsumsi $75 \%$ :

Tabel 1. Kandungan Nutrisi Singkong dan Nasi

\begin{tabular}{lll}
\hline Keterangan & Singkong & \multicolumn{1}{c}{ Nasi } \\
\hline Energi & $146 \mathrm{kkal}$ & $178 \mathrm{kkal}$ \\
\hline Protein & $1,2 \mathrm{gr}$ & $2,1 \mathrm{gr}$ \\
\hline Lemak & $0,3 \mathrm{gr}$ & $0,7 \mathrm{gr}$ \\
\hline Karbohidrat & $34,7 \mathrm{gr}$ & $40,6 \mathrm{gr}$ \\
\hline
\end{tabular}

Sumber:http://bkppp.bantulkab.go.id/ (2014)

Pengembangan agribisnis merupakan salah satu pilihan untuk meningkatkan kegiatan pertumbuhan ekonomi, karena PDB sektor pertanian yang tinggi dan dapat mendorong pertumbuhan sektor lainnya. Menurut Ketua Ikatan Sarjana Ekonomi Indonesia (2016) menyatakan bahwa PDB sektor pertanian berperan penting dengan kontribusinya sebesar $13,8 \%$ dengan menyerap tenaga kerja $35 \%$ dan apabila dihitung dari sektor hulu ke hilir kontribusinya mencapai 55\%. Artinya sektor pertanian yang dikembangkan dengan konsep agribisnis dapat mempengaruhi tingkat pertumbuhan ekonomi, didukung dengan pendekatan keunggulan daerah (comparative advantage) melalui nilai kearifan lokal.

Kota Cimahi merupakan salah satu kota berbasis industri yang memiliki lahan pertanian, terutama Kampung Adat Cireudeu, Desa Leuwigajah, Kecamatan Cimahi Selatan. Masyarakat memilih komoditas singkong sebagai komoditas unggulan di wilayahnya dalam melakukan kegiatan agribisnis. Adapun tujuan pemilihan komoditas singkong untuk mempertahankan budaya lokal dengan tidak memakan nasi, artinya wilayah ini memilih singkong sebagai makanan pokonya bukan nasi. Kegiatan agribisnis singkong yang dilakukan terdiri dari kegiatan produksi, industri, pemasaran, hingga ke sektor pariwisata dan masyarakat berhasil menciptakan beberapa produk olahan berupa beras singkong sebagai hasil kegiatan agroindustrinya.

Pengembangan agribisnis lain yang dilakukan Kampung Adat Cireundeu adalah agrowisata yang menawarkan wisata kuliner dan wisata edukasi memperkenalkan kegiatan bertani dan budaya sunda yang dijaga oleh masyarakat adat Cireundeu. Pengunjung Kampung Adat Cireundeu masih sedikit dan fluktuatif dibandingkan agrowisata lainnya dapat dilihat pada Tabel 2.

Tabel 2. Jumlah Pengujung Kampung Adat Cireundeu

\begin{tabular}{cc}
\hline Tahun & Jumlah Pengunjung \\
\hline 2011 & 1655 \\
\hline 2012 & 1890 \\
\hline 2013 & 1855 \\
\hline 2014 & 1780 \\
\hline 2015 & 2625 \\
\hline
\end{tabular}

Sumber: Kampung Adat Cireundeu (2016)

Hal tersebut menentukan sisi permintaan produk agroindustri singkong yang dikelola masyarakat karena Kampung Adat Cireundeu menawarkan wisata edukasi melalui budaya memakan nasi dari beras singkong. Setiap pengunjung yang datang ditawarkan mengkonsumsi nasi singkong sesuai dengan paket yang telah disediakan dalam kunjungan serta disediakan sarana rumah tinggal bagi pengunjung yang ingin menginap. Sedangkan untuk hasil agroindustri singkong lainnya bisa didapatkan di satu rumah warga yang dijadikan toko khusus penjualan produk masyarakat Kampung Adat Cireundeu. Hingga saat ini produk agroindustri singkong Kampung Adat Cireundeu kurang lebih 15 jenis produk.

Secara umum analisis lingkungan diperlukan untuk menentukan faktor-faktor utama yang mempengaruhi kegiatan agribisnis baik lingkungan dalam dan lingkungan luar oraganisasi. Faktor-faktor utama yang diperoleh akan menetukan perumusan strategi organisasi dan mengevaluasi kesesuaian strategi dalam mencapai tujuan. Beberapa faktor lingkungan yang selalu berubah menuntut 
Euis Dasipah, I. Iskandar, dan Rimelke R. Febryane: Kajian Pengembangan Agribisnis Singkong (Manihot Esculenta) Berbasis Kearifan Lokal Melalui Penerapan Agrowisata Di Kampung Cireundeu

kesiapan pengelola untuk melakukan perubahan-perubahan yang sesuai dengan kondisi dan situasi yang dihadapi dalam kegiatan agroindustri dan agrowisata yang dikelola Kampung Adat Cireundeu.

Tujuan dari penelitian ini sejalan dengan latar belakang dan perumusan masalah yang telah diuraikan, yaitu bertujuan untuk mempelajari:

1) Keterkaitan antara agroindustri singkong dan agrowisata di Kampung Adat Cireundeu.

2) Strategi yang tepat untuk dikembangkan Kampung Adat Cireundeu dalam mengembangkan agroindustri singkong berbasis kearifan lokal.

\section{LANDASAN TEORI}

Kearifan lokal dapat dipahami sebagai gagasan-gagasan setempat (local) yang bersifat bijaksana, penuh kearifan, bernilai baik, yang tertanam dan diikuti oleh anggota masyarakatnya. Kearifan lokal mencerminkan sebuah budaya setempat dan J.W. Ajawaila (1991) berpendapat bahwa budaya lokal merupakan ciri khas budaya sebuah kelompok masyarakat lokal (dalam Asmiawati, 2016). Adapun Judistira (2008) mengatakan bahwa kebudayaan daerah bukan hanya terungkap dari bentuk dan pernyataan rasa keindahan melalui kesenian belaka tetapi termasuk segala bentuk dan cara-cara berperilaku, bertindak, serta pola pikiran yang berada jauh dibelakang apa yang tampak tersebut. Salah satu bentuk dari kearifan lokal adalah budaya lokal yang biasanya dimiliki oleh daerah tertentu atau kelompok masyarakat tertentu.

Budaya lokal merupakan cerminan dan ciri khas suatu wilayah yang dapat ditunjukan dari adat, kemampuan wilayah, bahkan bangunan yang dimiliki sebuah wilayah. Budaya lokal akan berperan sebagai sarana kekuatan wilayah dalam menciptakan suatu kegiatan ekonomi salah satunya sektor pertanian. Dalam kegiatan pertanian tersebut dapat dilakukan kegiatan pengembangan agribisnis berupa agrowisata dan agroindustri. Agrowisata dalam budaya lokal adalah sarana pemasaran dan pengenalan wilayah sehingga dapat menghasilkan pendapatan melalui pengunjung, sedangkan agroindustri merupakan sarana pengembangan agribisnis dalam menciptakan produk dari komoditas unggulan sehingga nilai tambahnya menjadi pendapatan wilayah.

Pada dasarnya agrowisata dalam sebuah wilayah memiliki peran dalam perkembangan agroindustri karena akan menentukan jumlah permintaan produk yang terdapat dalam wilayah. Agrowisata merupakan aktivitas yang melibatkan lahan pertanian atau fasilitas lain sebagai daya tarik wilayah menarik pengunjung. Faktor yang menentukan banyaknya pengunjung yaitu, wisata yang ditawarkan, fasilitas terkait yang dimiliki dan jarak yang perlu ditempuh pengunjung dari pusat kota. Adapun analisis yang dapat dilakukan untuk mengetahui tingkat permintaan produk dapat dilakukan secara deskriptif melalui analisis persepsi pengunjung terhadap produk pertanian yang diproduksi oleh pengelola atau masyarakat sekitarnya. Selain itu, persepsi pengunjung digunakan untuk mengetahui tingkat kepuasan konsumen melalui tingkat kompetensi yang dinilai berpengarh besar dalam keberlangsungan pengembangan agribisnis. Untuk melengkapi penilaian pegunjung terhadap produk dan pelayanan yang diberikan diperlukan juga analisis keinginan membayar (willingness to pay) agar produsen dapat mengetahui kemampuan, kebutuhan, dan kepuasan konsumen dalam menggunakan produk dan pelayanan yang diberikan produsen.

Banyaknya pengunjung akan mencerminkan keberhasilan agrowisata dan mempengaruhi jumlah produk wilayah yang terjual karena agrowisata berfungsi sebagai sarana pemasaran dan pengenalan produk pertanian biasa ataupun hasil agroindustri 
setempat. Agroindustri akan menentukan jumlah penawaran dalam suatu wilayah karena menunjukan kemampuan wilayah dalam memproduksi produk. Agroindustri adalah proses merubah bahan baku menjadi produk yang menghasilkan nilai tambah. Keberhasilan strategi dalam melakukan agroindustri dapat dianalisis melalui keadaan lingkungan baik secara internal dan eksternal. Secara eksternal agroindustri dapat dikaji melalui aspek sosial, ekonomi, kebijakan, dan hubungan antar sektor atau instansi lainnya, sedangkan secara internal dapat dikaji dengan meninjau kegiatan agribisnis dari hulu sampai hilir. Kedua analisis tersebut dilakukan dengan analisis deskriptif kualitatif yang ditunjang menggunakan analisis kuantitatif.

Menurut T. Hani Handoko (1999), lingkungan eksternal terbagi menjadi dua kelompok lingkungan yaitu, lingkungan eksternal mikro dan lingkungan eksternal makro. Lingkungan mikro merupakan lingkungan yang terdiri atas pelaku-pelaku dalam lingkungan perusahaan seperti pemasok, pelanggan, dan pesaing. Sedangkan lingkungan makro adalah lingkungan yang terdiri dari kekuatankekuatan sosial yang lebih besar seperti, demografi, ekonomi, sosial, budaya, politik, ekologi, dan teknologi. Sifat dari lingkungan makro ini tidak dapat dikendalikan karena proses perubahannya sangat cepat sehingga sulit untuk dianalisis, tetapi lingkungan ini memiliki kecenderungan reaktif terhadap pencapaian tujuan wilayah. Adapun lingkungan internal merupakan lingkungan yang berkaitan dengan keadaan di dalam wilayah dan berpengaruh langsung terhadap pencapaian tujuan wilayah. Lingkungan internal terdiri dari aspek produksi, keuangan, pemasaran, dan sumber daya manusia.

Agroindustri dapat dianalisis secara makro melalui perusahaan lain sejenis dan kebijakan pemerintah sedangkan secara mikro dapat dianalisis melalui hubungan konsumen serta perubahan konsumen. Adapun faktor-faktor penentu keberhasilan internal wilayah dapat dianalisis dari ketersediaan lahan, pemilihan bahan baku, penerapan teknologi, pendidikan, pengalaman, struktur wilayah, ketersediaan tenaga kerja, sumber modal, saluran tataniaga, promosi, harga sarana produksi, harga produk, dan kualitas produk.

Indonesia memiliki beranekaragam budaya lokal yang berpotensi dan memiliki keunggulan daerah (comparative advantage) untuk dikembangkan dalam kegiatan agribisnis, tetapi perlu diperhatikan juga mengenai perubahan lingkungan karena akan mempengaruhi proses perencanaan dan pengambilan keputusan sehingga produk yang dihasilkan memiliki daya saing (competitive advantage). Pada umumnya analisis lingkungan yang dilakukan di Indonesia perlu disesuaikan dengan keunggulan daerah (comparative advantage), baik dari segi keunggulan komoditas, keunggulan wilayah berdasarkan nilai kearifan lokal berupa budaya atau kemampuan wilayah.

Perubahan yang terjadi dalam kegiatan agribisnis baik di lingkungan internal maupun lingkungan eksternal akan mempengaruhi keadaan persaingan ekonomi. Proses analisis lingkungan internal dan lingkungan eksternal wilayah akan membuat pengelola mengetahui kekuatan dan kelemahan yang dimiliki dan mengetahui peluang dan ancaman yang dapat timbul didalam pencapaian tujuannya. Lingkungan internal dan lingkungan eksternal mempengaruhi wilayah dalam proses perencanaan dan pengambilan keputusannya. Untuk melakukan atau melaksanakan proses perencanaan dan pengambilan keputusan, maka terlebih dahulu perusahaan harus menganalisa lingkungannya. Tahap analisis yang dilakukan terdiri dari 3 tahap yaitu, tahap pemasukan (input stage), tahap pencocokan (matching stage), dan tahap pengambilan keputusan (decision stage) (David, 2010).

Tahap pemasukan merupakan tahap analisis lingkungan internal dan analisis lingkungan eksternal. Menurut Kotler (1997), analisis lingkungan internal dapat memberikan gambaran kondisi suatu 
Euis Dasipah, I. Iskandar, dan Rimelke R. Febryane: Kajian Pengembangan Agribisnis Singkong (Manihot Esculenta) Berbasis Kearifan Lokal Melalui Penerapan Agrowisata Di Kampung Cireundeu

wilayah. Faktor internal yang dianalisis adalah struktur wilayah, faktor pemasaran, penelitian dan pengembangan, produksi, sumber daya dan karyawan wilayah dan lain-lain. Sedangkan analisis lingkungan eksternal dilakukan untuk mengetahui perubahan lingkungan eksternal yang akan mempengaruhi peluang dan ancaman dalam sebuah wilayah. Tahap selanjutnya adalah tahap pencocokan menggunakan analisis SWOT. Menurut David (2008), analisis SWOT adalah analisis yang digunakan untuk mengevaluasi kekuatan (strengths), kelemahan (weaknesses), peluang (opportunities), dan ancaman (threats) dalam suatu perencanaan strategis wilayah. Dalam proses analisis tersebut faktor internal dan faktor eksternal akan dikombinasikan sehingga menghasilkan sebuah tujuan spesifik wilayah.

Kekuatan adalah kemampuan wilayah berupa sumber daya, keterampilan, keunggulan atau kompetensi khusus yang memberikan keunggulan komparatif perusahaan di pasar. Kampung Cirendeu merupakan Desa Wisata Ketahanan Pangan yang menghasilkan produk olahan berupa beras singkong (rasi), dendeng kulit singkong, eggroll, dan sebagainya. Adanya hal terebut menunjukan bahwa Kampung Adat Cireundeu memiliki kekuatan berupa ketersediaan lahan, bahan baku, dan sumber daya manusia yang dapat menghasilkan produk-produk agroindustri yang bersaing seiring dengan keadaan daerah yang memiliki budaya lokal makan singkong. Selain itu, produk tersebut juga memiliki harga jual yang bersaing dengan produk sejenis lainnya dan memiliki kualitas yang baik.

Kelemahan adalah keterbatasan perusahaan baik sumber daya, penentuan harga dan promosi yang dilakukan oleh pengelola. Semua komponen dapat menjadi kelemahan wilayah walaupun dalam beberapa kasus, kelemahan dapat menjadi kekuatan dalam perusahaan melalui proses evaluasi. Kampung Adat Cireundeu yang masih memegang nilai adat terkadang sulit menerima teknologi baru untuk meningkatkan efisiensi produksi, selain itu sumber modal juga masih terbatas sehingga produksi belum maksimal dan kegiatan pemasaran terhambat.

Peluang adalah situasi penting yang menguntungkan dalam wilayah. Identifikasi segmen pasar yang tadinya terabaikan, perubahan situasi persaingan, peraturan pemerintah, perubahan teknologi serta membaiknya hubungan dengan konsumen atau dengan pemasok akan mempengaruhi nilai peluang yang dapat dimanfaatkan perusahaan. Kecenderungan-kecenderungan yang penting sebagai salah satu sumber peluang yang menimbulkan wilayah mengalami pertumbuhan dan mendapatkan keuntungan. Peluang yang dimiliki Kampung Adat Cireundeu selain pesaing sejenis dan hubungan konsumen adalah nilai budaya lokal karena mempengaruhi nilai jual agribisnis yang dimiliki Kampung Adat Cireundeu sehingga pelayanan yang diberikan menjadi berbeda dengan pengembang usaha lainnya.

Ancaman merupakan situasi penting yang tidak menguntungkan dalam wilayah. Ancaman dapat menjadi penggangu utama dalam sebuah posisi wilayah. Memahami peluang-peluang dan ancaman-ancaman utama yang dihadapi wilayah membantu pengelola untuk mengidentifikasikan strategi yang realistis dan cocok yang paling efektif bagi wilayah. Ancaman yang dihadapi Kampung Adat Cireundeu adalah kebijakan pemerintah, perubahan selera konsumen, aksesbilitas, dan fasilitas serta keindahan alam yang dimilikinya. Keindahan alam yang sangat dijaga oleh masyarakat adat ini cukup menghambat pemilihan strategi yang akan dipilih untuk pengembangan agribisnisnya.

Suatu wilayah dapat mengembangkan dan mengevaluasi strategi untuk mengatasi ancaman dan merebut peluang yang ada. Proses analisis, perumusan dan evaluasi tersebut disebut perencanaan strategis 
(Rangkuti, 2001). Analisis pertumbuhan ekonomi wilayah dan analisis lingkungan akan memberikan gambaran mengenai kekuatan dan kelemahan internal perusahaan serta peluang dan ancaman eksternal yang dihadapi wilayah dalam melaksanakan pembangunannya. Dengan analisis SWOT pengelola diharapkan dapat merumuskan strategi bersaing berdasarkan perpaduan faktor internal dan eksternal tersebut. Strategi pengembangan agroindustri wilayah berdasakan analisis SWOT dilakukan melalui empat strategi yaitu strategi S-O, W-O, S-T dan W-T (David dalam Husein Umar, 2001). Kemudian diperoleh alternatif strategi yang terbaik dan tepat bagi perusahaan yang ditunjukan oleh posisi wilayah pada matrik SWOT yang dianalisis. Pada dasarnya pengelola harus mampu mengevaluasi diri dalam hal kemampuan mengantisipasi kemungkinan perubahan yang terjadi dalam persaingan pasar.

\section{METODE}

Metode penelitian yang digunakan dalam penelitian ini adalah metode Studi Kasus (Case Study), yaitu salah satu penelitian deskriptif, yang bertujuan untuk mempelajari latar belakang keadaan sekarang dan interaksi lingkungan dari suatu unit sosial/ institusi secara lebih mendalam (intensif). Creswell (2009) menyatakan peneliti akan menyelidiki secara cermat suatu peristiwa, aktifitas, proses, program, atau sekelompok individu agar peneliti mengetahui gambaran suatu kasus secara detail, sedangkan SulistyoBasuki (2010) berpendapat bahwa studi kasus akan menghasilkan penelitian yang bersifat khusus, tidak dapat dibuat rampadan (generalisasi). Artinya penelitian ini menekankan usaha dalam menggali informasi mengenai gejala pada saat unit yang diteliti, memberikan gambaran terhadap fenomena-fenomena, juga menerangkan hubungan dan menarik makna dari suatu masalah yang diteliti sehingga akan nampak kekhasan penelitiannya. Selain mempelajari latar belakang keadaan yang diteliti, penelitian ini dilengkapi dengan studi kepustakaan terhadap literatur dan laporan yang berkaitan. Dengan demikian yang dijadikan kasus dalam penelitian ini adalah pengembangan agribisnis singkong di Kampung Adat Cireundeu melalui penerapan agroindustri dan agrowisata.

Data yang perlu dikumpulkan dari sebagian populasi yang mewakili suatu populasi dan yang menjadi unit analisisnya. Populasi yang dimaksud adalah pakar pengembangan agroindustri dan pengujung agrowisata di Kampung Adat Cireundeu, Kelurahan Leuwigajah, Kecamatan Cimahi Selatan, Kota Cimahi sebanyak 37 responden dengan penentuan sampling purposive (sengaja). Proses penelitian di lapangan dan pengolahan data ini berlangsung selama 2 bulan yang terdiri dari kegiatan observasi, wawancara, dan studi pustaka. Adapun alat analisis yang digunakan yaitu, persepsi pengunjung, WTP, IFE, EFE, dan SWOT.

\section{1) Persepsi pengunjung}

Analisis persepsi pengunjung Agrowisata Kampung Adat Cireundeu bertujuan untuk mengetahui persepsi yang muncul mengenai Agrowisata Kampung Adat Cireundeu khususnya produk beras singkong (rasi) berdasarkan pengamatan pengunjung dalam melihat kawasan serta merasakan produk yang dihasilkan Kampung Adat Cireundeu. Selain itu, persepsi yang dinilai akan menunjukan tingkat kepuasan pengunjung dan konsumen. Tingkat kompetensi yang dinilai untuk mengetahui persepsi pengunjung yaitu, kualitas produk, kemasan produk, umur pakai/ kadaluarsa produk, aksesbilitas, fasilitas, pelayanan, budaya lokal, dan harga produk.

Untuk menghitung dan menggabungkan seluruh tingkat kompetensi menjadi tingkat kepuasan pengunjung, maka setiap kompetensi yang mencakup keseluruhan aspek kepuasan peengunjung diterjemahkan kedalam bentuk bobot relatif dengan skala antara 0,01 s.d 1,00 sebagai berikut: 
Euis Dasipah, I. Iskandar, dan Rimelke R. Febryane: Kajian Pengembangan Agribisnis Singkong (Manihot Esculenta) Berbasis Kearifan Lokal Melalui Penerapan Agrowisata Di Kampung Cireundeu

Tabel 3. Analisis Persepsi Pengunjung Kampung Adat Cireundeu

\begin{tabular}{ccccc}
\hline No. & Kompetensi & Bobot & Rating & Nilai \\
\hline 1 & & & & \\
\hline 2 & & & & \\
\hline$\ldots$. & & & \\
\hline & Total & 1 & \\
\hline
\end{tabular}

Tabel analisis persepsi pengunjung ini merupakan metode untuk menganalisis faktor internal yang dimiliki produk dan pelayanan, penggunaan metode ini adalah sebagai berikut :

a. Pada kolom 1, tentukan faktor - faktor penentu daya saing produk

b. Pada kolom 2, beri bobot pada setiap faktor dari 0,0 (tidak penting) sampai 1,0 (paling penting) berdasarkan pengaruh faktor - faktor tersebut jumlah semua bobot harus sama dengan 1,0

Adapun penentuan bobot setiap variabel dilakukan dengan cara mengajukan identifikasi faktor-faktor tersebut kepada pihak manajemen perusahaan dan konsumen dengan menggunakan metode Paired Comparison (David, 2006). Metode ini digunakan untuk memberikan penilaian terhadap bobot setiap kompetensi persepsi pengunjung dengan cara membandingkan variabel horisontal terhadap variabel vertikal. Bobot setiap variabel diberi nilai 1,2,3 dimana nilai tersebut adalah sebagai berikut :

Nilai $1=$ Jika indikator horisontal kurang penting daripada indikator vertikal

Nilai $2=$ Jika indikator horisontal sama penting daripada indikator vertikal

Nilai $3=$ Jika indikator horisontal lebih penting daripada indikator vertikal

Tabel 4. Penilaian Bobot Faktor Strategis (Metode Paired Comparison).

$\begin{array}{cccccccc}\text { Kompetensi } & 1 & 2 & \ldots & \text { Jumlah } & \text { Bobot Rating Nilai }\end{array}$

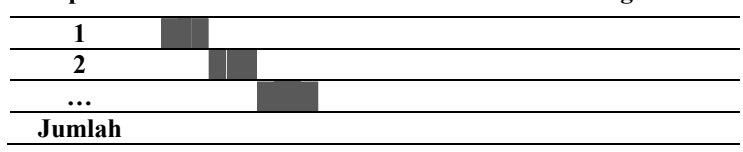

Sumber: David,2006.

Bobot setiap variabel diperoleh dengan menentukan nilai setiap variabel dengan menggunakan rumus :

$$
a_{i}=\frac{X_{i}}{\sum_{i=1}^{n} X_{i}}
$$

Keterangan :

$\mathrm{a}_{\mathrm{i}}=$ bobot variabel ke- $\mathrm{i}$

$\mathrm{X}_{\mathrm{i}}=$ nilai variabel ke- $\mathrm{i}$

$\mathrm{i}=1,2,3, \ldots . . \mathrm{n}$

$\mathrm{n}=$ jumlah variabel

c. Pada kolom 3, diberi rating mulai dari 1 sampai dengan 4 untuk masing- masing faktor dimana :

Nilai $1=$ Kelemahan utama

Nilai $3=$ Kekuatan kecil

Nilai $2=$ Kelemahan kecil

Nilai $4=$ Kekuatan utama

d. Pada kolom 4, kalikan bobot pada kolom 2 dengan rating pada kolom 3 untuk memperoleh bobot skor masingmasing.

e. Bobot skor pada kolom 4 untuk memperoleh total skor pembobotan bagi perusahaan yang bersangkutan. Nilai total ini menunjukkan bagaimana organisasi bereaksi terhadap faktorfaktor strategis internal.

Dalam tabel analisis persepsi pengunjung, total skor pembobotan berkisar dari 1,0 yang rendah sampai 4,0 yang tinggi, dengan rata-rata 2,5. Maka keputusan yang dapat diambil adalah sebagai berikut :

- Jika total skor berkisar $<1,0$ maka dapat disimpulkan bahwa kepuasan pengunjung rendah.

- Jika total skor berkisar antara 1,0 2,5 maka dapat disimpulkan bahwa kepuasan pengunjung sedang (standar).

- Jika total skor berkisar antara 2,5 4,0 maka dapat disimpulkan bahwa kepuasan pengunjung tinggi. 
Penilaian lainnya dalam analisis persepsi pengunjung adalah analisis deskriptif mengenai alasan pengunjug memilih Kampung Adat Cireundeu untuk dikunjungi dan mengetahui jenis olahan singkong yang diminat pengunjung akan disajikan dalam bentuk persentase. Hasil tersebut akan menunjukan keterkaitan agrowisata dan agroindustri yang ada di Kampung Adat Cireundeu.

\section{2) WTP}

Data harga yang diperoleh akan diolah untuk mendapatkan nilai persentase dari jumlah keseluruhan kategori yang telah diamati dan memberikan gambaran umum tentang data yang diperoleh. Harga produk serta tarif yang akan didapatkan berasal dari wawancara langsung terhadap responden. Untuk megetahui harga produk dan tarif yang yang sesuai dengan agrowisata ini dilakukan 3 tahap pengolahan data, yaitu: (Fauzi,2006)

a. Membuat hipotesis pasar

Proses membangun pasar hipotesis mengenai sumberdaya yang akan dievaluasi. Hipotesis dibantu melalui kuesioner.

b. Mendapatkan nilai lelang (bids)

Nilai lelang didapatkan dari hasil survey dan wawancara kepada responden melalui kuesioner. Tujuannya untuk mengetahui nilai keinginan membayar yang maksimum.

c. Menghitung rataan WTP

Nilai yang diperoleh dari jumlah keseluruhan nilai WTP yang diberikan oleh setiap responden kemudian dibagi oleh jumlah responden. Perhitungan nilai WTP dengan rumus:

Keterangan:

$$
\sum W T P=\frac{\sum_{i=1}^{n} W i}{n}
$$

$\sum$ WTP: Dugaan rataan WTP (Rp.)

Wi : Nilai WTP ke-i

$\mathrm{n}$ : jumlah responden yang bersedia membayar (orang)

i : responden ke-i yang bersedia membayar tarif

Apabila rentang data jauh, maka nilai dugaan rataan WTP yang digunakan merupakan hasil perhitungan median dari data yang diperoleh dan diakumulasikan dalam bentuk persentase.

3) IFE \& EFE

Analisis merupakan proses menganalisis lingkungan untuk mengetahui faktor internal dan eksternal yang dimiliki oleh Kampung Cireundeu agar teridentifikasi kekuatan, kelemahan, peluang, dan ancaman perusahaan. Alat yang digunakan dalam tahap analisis ini yaitu, matriks IFE (Internal Factor Evaluation) dan matriks EFE (External Factor Evaluation). Kemudian dilakukan perhitungan nilai keseluruhan dari kedua matriks tersebut. Untuk mendapatkan matriks IFE dan matriks EFE dilakukanlah langkah-langkah berikut :

a. Menetukan faktor internal (kekuatan dan kelemahan) dan eksternal (peluang dan ancaman) pada kolom satu. Untuk mendapatkan variabel-variabel tersebut dilakukan dengan melakukan analisis deskriptif. Masukan 6 hingga 20 faktor dan dibuat secara spesifik.

b. Memberikan bobot pada faktor tersebut dengan kisaran 0,0 (tidak penting) sampai 1,0 (sangat penting). Bobot mengindikasikan signifikansi relatif suatu faktor terhadap keberhasilan perusahaan. Jumlah total seluruh bobot yang diberikan pada faktor-faktor tersebut harus sama dengan 1,0. Penentuan bobot dilakukan dengan metode perbandingan berpasangan (Paired Comparison Method) (David, 2006). Penentuan bobot dilakukan oleh tiga responden yang mengetahui kondisi internal dan eksternal dari perusahaan. Metode ini digunakan untuk memberikan penilaian terhadap bobot setiap faktor penentu internal dan eksternal perusahaan. Untuk menentukan bobot setiap variabel digunakan skala 1,2 , dan 
Euis Dasipah, I. Iskandar, dan Rimelke R. Febryane: Kajian Pengembangan Agribisnis Singkong (Manihot Esculenta) Berbasis Kearifan Lokal Melalui Penerapan Agrowisata Di Kampung Cireundeu

3. Skala yang digunakan untuk pengisian kolom adalah :

$1=$ Jika indikator horisontal kurang penting daripada indikator vertikal

$2=$ Jika indikator horisontal sama dengan daripada indikator vertikal

$3=$ Jika indikator horisontal lebih penting daripada indikator vertikal. Bobot adalah bilangan yang nilainya ditentukan berdasarkan total skor tiap faktor dari responden yang dibagi dengan total skor keseluruhan faktor. Bentuk penilaian pembobotan matriks IFE dan EFE dapat dilihat pada Tabel 5, sebagai berikut :

Tabel 5. Penilaian Bobot Faktor Internal dan Eksternal Perusahaan (Matriks IFE)

\begin{tabular}{|c|c|c|c|c|c|c|}
\hline No & $\begin{array}{c}\text { Faktor } \\
\text { Internal/Eksternal }\end{array}$ & A B & C & $\ldots$ & $\begin{array}{l}\text { Total } \\
\text { (Xi) }\end{array}$ & Bobot \\
\hline 1 & $\mathrm{~A}$ & & & & & \\
\hline 2 & B & & & & & \\
\hline 3 & $\mathrm{C}$ & & & & & \\
\hline 4 & …….. & & & & & \\
\hline & Total & & & & & 1,0 \\
\hline
\end{tabular}

Sumber: David, (2006).

Bobot setiap variabel diperoleh dengan menentukan nilai setiap variabel terhadap jumlah nilai keseluruhan variabel menggunakan rumus :

$$
\alpha_{1}=\frac{X_{i}}{\sum_{i=1}^{n} X_{i}}
$$

Keterangan :

$\alpha_{\mathrm{i}}=$ bobot variabel ke-i $\quad \mathrm{i}=1,2,3,4, \ldots . . \mathrm{n}$

$\mathrm{X}_{\mathrm{i}}=$ nilai variabel ke-I $\mathrm{n}=$ jumlah variabel

c. Memberi peringkat 1 sampai 4 pada setiap faktor internal dan eksternal utama untuk menunjukan seberapa efektif strategi perusahaan saat ini dalam merespon faktor tersebut, dimana $4=$ responnya sangat bagus, $3=$ responnya diatas rata-rata, $2=$ responnya rata-rata, $1=$ responnya dibawah rata-rata. Peringkat adalah suatu nilai atau wujud yang

diberi tingkatan dari besar ke kecil atau sebaliknya. Peringkat didasarkan pada keefektifan strategi. Penentuan peringkat dapat disajikan pada Tabel 6 yaitu sebagai berikut :

Tabel 6. Peringkat Faktor Internal/Eksternal

\begin{tabular}{|c|c|c|c|c|c|}
\hline \multirow{2}{*}{$\begin{array}{c}\text { Faktor } \\
\text { Internal/Eksternal } \\
\text { Strategis } \\
\end{array}$} & \multicolumn{4}{|c|}{ Peringkat } & \multirow{2}{*}{$\begin{array}{r}\text { Rata- } \\
\text { rata }\end{array}$} \\
\hline & 1 & 2 & 3 & 4 & \\
\hline \multicolumn{6}{|l|}{$\mathrm{A}$} \\
\hline \multicolumn{6}{|l|}{ B } \\
\hline \multicolumn{6}{|l|}{$\mathrm{C}$} \\
\hline \multicolumn{6}{|l|}{$\mathrm{D}$} \\
\hline Total & & & & & \\
\hline
\end{tabular}

Sumber: David,(2006).

d. Mengalikan bobot setiap faktor dengan peringkatnya untuk menentukan skor bobot.

e. Jumlahkan skor rata-rata untuk setiap variabel guna menentukan skor bobot total untuk perusahaan. Nilai total skor berkisar 1,0 sampai 4,0 pada matriks IFE dan EFE. Maka kaidah keputusan yang dapat dipilih adalah sebagai berikut :

- Jika total skor $<2,5$ maka dapat disimpulkan bahwa keadaan internal perusahaan lemah untuk matriks IFE dan perusahaan tidak merespon dengan baik peluang serta ancaman untuk matriks EFE.

- Jika total skor > 2,5 maka dapat disimpulkan bahwa keadaan internal perusahaan kuat untuk matriks IFE dan perusahaan merespon dengan baikpeluang dan ancaman untuk matriks EFE.

Penyajian hasil analisis IFE/EFE ada pada matriks seperti dibawah ini :

Tabel 7. Matriks IFE/EFE

\begin{tabular}{|c|c|c|c|}
\hline $\begin{array}{c}\text { Faktor-Faktor } \\
\text { Internal/Ekster } \\
\text { nal }\end{array}$ & $\begin{array}{c}\text { Bob } \\
\text { ot } \\
\left(\mathbf{X}_{\mathbf{i}}\right)\end{array}$ & $\begin{array}{c}\text { Peringk } \\
\text { at }\left(Y_{i}\right)\end{array}$ & $\begin{array}{c}\text { Skor } \\
\text { Pembobot } \\
\text { an }\left(X_{i} Y_{i}\right)\end{array}$ \\
\hline
\end{tabular}

Kekuatan

1. 
Kelemahan

1 .

\begin{tabular}{ccc}
\hline Total & $\sum \mathrm{X}_{\mathrm{i}}=$ & $\sum \mathrm{Y}_{\mathrm{i}}=1,0$ \\
& 1,0 & \\
\hline
\end{tabular}

Sumber: David,2006.

\section{4) SWOT}

Analisis dengan matriks SWOT digunakan untuk menentukan alternatif rancangan strategi dengan mempertimbangkan kekuatan, kelemahan, peluang, dan ancaman. Dalam mengembangkan matriks SWOT hal tersulit adalah mencocokan faktor-faktor internal dan eksternal utama dan membutuhkan penilaian yang baik. Penentuan analisis SWOT dilakukan setelah menentukan kekuatan, kelemahan, peluang, dan ancaman yang diperoleh dari hasil identifikasi matriks IFE dan EFE. Penetapan atau rumusan strategi dilakukan dengan menggunakan strategi $\mathrm{S}-\mathrm{O}, \mathrm{W}-\mathrm{O}, \mathrm{S}-$ $\mathrm{T}$, dan $\mathrm{W}-\mathrm{T}$. Penyajian rumusan strategi dilakukan dengan menggunakan matriks Strategi SWOT dibawah ini :

\begin{tabular}{|c|c|c|}
\hline Faktor Internal & $\begin{array}{l}\text { KEKUATAN } \\
\text { (S) }\end{array}$ & $\begin{array}{l}\text { KELEMAHAN } \\
\text { (W) }\end{array}$ \\
\hline $\begin{array}{l}\text { Faktor } \\
\text { Eksternal }\end{array}$ & $\begin{array}{c}\text { Daftar } \\
\text { kekuatan- } \\
\text { kekuatan } \\
\text { Internal }\end{array}$ & $\begin{array}{l}\text { Daftar } \\
\text { kelemahan- } \\
\text { kelemahan } \\
\text { Internal }\end{array}$ \\
\hline $\begin{array}{c}\text { PELUANG } \\
(\mathrm{O})\end{array}$ & $\begin{array}{c}\text { STRATEGI } \\
\text { S-O }\end{array}$ & $\begin{array}{c}\text { STRATEGI } \\
\text { W-O }\end{array}$ \\
\hline $\begin{array}{c}\text { Daftar peluang- } \\
\text { peluang } \\
\text { Eksternal }\end{array}$ & $\begin{array}{c}\text { Strategi } \\
\text { dengan } \\
\text { menggunakan } \\
\text { kekuatan } \\
\text { untuk } \\
\text { memanfaatkan } \\
\text { peluang }\end{array}$ & $\begin{array}{c}\text { Strategi dengan } \\
\text { memanfaatkan } \\
\text { peluang untuk } \\
\text { mengatasi } \\
\text { kelemahan }\end{array}$ \\
\hline $\begin{array}{l}\text { ANCAMAN } \\
\text { (T) }\end{array}$ & $\begin{array}{l}\text { STRATEGI } \\
\text { S-T }\end{array}$ & $\begin{array}{c}\text { STRATEGI } \\
\text { W-T }\end{array}$ \\
\hline $\begin{array}{c}\text { Daftar } \\
\text { ancaman- } \\
\text { ancaman } \\
\text { Eksternal }\end{array}$ & $\begin{array}{c}\text { Strategi } \\
\text { dengan } \\
\text { menggunakan } \\
\text { kekuatan } \\
\text { untuk } \\
\text { menghindari } \\
\text { ancaman }\end{array}$ & $\begin{array}{c}\text { Strategi dengan } \\
\text { meminimumkan } \\
\text { kelemahan dan } \\
\text { menghindari } \\
\text { ancaman }\end{array}$ \\
\hline
\end{tabular}

Sumber: Rangkuti (2008)

Gambar 2. Matrik SWOT
Pada analisis selanjutnya akan dikembangkan analisis secara kuantitatif yakni hasilnya akan menentukan posisi organisasi. Penentuan posisi kuadran diperoleh dari titik tertinggi yang ada di faktor internal dan faktor eksternal. Posisi tersebut disajikan dalam kuadran SWOT sebagai berikut:

a. Kuadran I

Posisi ini menandakan sebuah orgnisasi yang kuat dan berpeluang. Rekomendasi strategi yang diberikan adalah Progresif, artinya organisasi dalam kondisi prima dan mantap sehingga sangat dimungkinkan untuk terus melakukan ekspansi, memperbesar pertumbuhan dan meraih kemajuan secara maksimal.

b. Kuadran II

Posisi ini menandakan sebuah organisasi yang kuat namun menghadapi tantangan yang besar. Rekomendasi strategi yang diberikan adalah Diversifikasi Strategi, artinya organisasi dalam kondisi mantap namun menghadapi sejumlah tantangan berat sehingga diperkirakan roda organisasi akan mengalami kesulitan untuk terus berputar bila hanya bertumpu pada strategi sebelumnya. Oleh karena itu, organisasi disarankan untuk segera memperbanyak ragam strategi taktisnya.

c. Kuadran III

Posisi ini menandakan sebuah organisasi yang lemah namun sangat berpeluang. Rekomendasi strategi yang diberikan adalah Ubah Strategi, artinya organisasi disarankan untuk mengubah strategi sebelumnya. Sebab, strategi yang lama dikhawatirkan sulit untuk dapat menangkap peluang yang ada sekaligus memperbaiki kinerja organisasi.

d. Kuadran IV 
Euis Dasipah, I. Iskandar, dan Rimelke R. Febryane: Kajian Pengembangan Agribisnis Singkong (Manihot Esculenta) Berbasis Kearifan Lokal Melalui Penerapan Agrowisata Di Kampung Cireundeu

Posisi ini menandakan sebuah organisasi yang lemah dan menghadapi tantangan besar. Rekomendasi strategi yang diberikan adalah Strategi Bertahan, artinya kondisi internal organisasi berada pada pilihan dilematis. Oleh karenanya organisasi disarankan untuk meenggunakan strategi bertahan, mengendalikan kinerja internal agar tidak semakin terperosok. Strategi ini dipertahankan sambil terus berupaya membenahi diri.

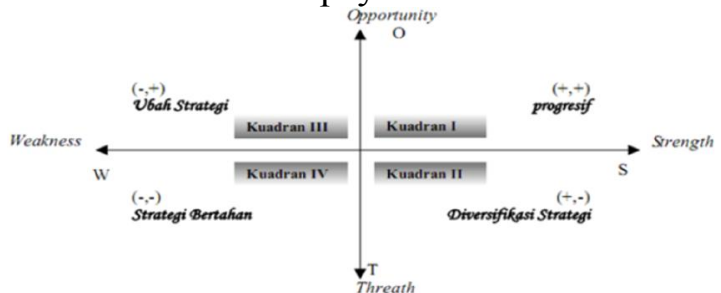

Sumber: Rangkuti, (2008)

Gambar 3. Kuadran Strategi SWOT

\section{HASIL DAN PEMBAHASAN}

\section{1) Persepsi Pengunjung}

Analisis persepsi pengunjung dilakukan untuk mengukur kepuasan pengunjung terhadap produk agrowisata dan agroindustri yang diberikan Kampung Adat cireundeu. Persepsi pengunjung sangat bergantung pada tingkat kompetensi pelayanan dan penawaran yang dilakukan Kampung Adat Cireundeu dalam pengembangan agribisnisnya. Setiap tingkat kompetensi memiliki bobot relatif yang berbeda, bergantung pada persepsi pengelola perusahaan (internal) dan persepsi stakeholders atau masyarakat konsumen (eksternal) terhadap sebuah produk yang dipilih. Secara umum, hasil analisis persepsi pengunjung dalam tabel menunjukan total skor pembobotan sebesar 3,21. Skor pembobotan tersebut menunjukan bahwa pengunjung puas dengan pelayanan yang diberikan Kampung Adat Cireundeu baik untuk produk agrowisata maupun produk agroindustri.
Dari skor tersebut diketahui bahwa kepuasan pengunjung baik.

Aspek yang dinilai dalam persepsi pengunjung lainnya adalah mengamati minat pengunjung terhadap pembelian produk olahan singkong lainnya. Dari 30 responden, $60 \%$ responden yang memiliki minat membeli produk olahan singkong seperti keterangan pada pada Tabel 8 .

Tabel 8. Pilihan konsumen mengenai olahan singkong lainnya

\begin{tabular}{llcc}
\hline No. & $\begin{array}{l}\text { Nama } \\
\text { Produk }\end{array}$ & $\begin{array}{l}\text { Jumlah } \\
\text { Konsumen }\end{array}$ & $\begin{array}{c}\text { Persentase } \\
(\mathbf{\%})\end{array}$ \\
\hline 1 & Eggroll & 9 & 47 \\
\hline 2 & Simping & 3 & 16 \\
\hline 3 & Kripik & 4 & 21 \\
\hline 4 & Pastel & 1 & 5 \\
\hline 5 & Dendeng & 2 & 11 \\
& $\begin{array}{l}\text { Kulit } \\
\text { Singkong }\end{array}$ & & \\
\hline & Total & 19 & 100 \\
\hline
\end{tabular}

Artinya adanya agrowisata menarik pengunjung untuk mengkonsumsi produk olahan singkong selain rasi dan produk yang paling diminati adalah eggroll yang berasal dari singkong. Adapun alasan pengunjung datang ke Kampung Adat Cireundeu dari 30 responden dapat dilihat pada Tabel 9.

Tabel 9. Alasan pengunjung datang ke Kampung Adat

\begin{tabular}{|c|c|c|c|}
\hline No. & $\begin{array}{l}\text { Alasan } \\
\text { berkunjung }\end{array}$ & $\begin{array}{l}\text { Jumlah } \\
\text { Konsumen }\end{array}$ & $(\%)$ \\
\hline 1 & Rekreasi & 2 & 7 \\
\hline 2 & Tugas dan riset & 5 & 16 \\
\hline 3 & $\begin{array}{l}\text { Ingin mencoba } \\
\text { rasi } \\
\text { mengetahui } \\
\text { budayanya }\end{array}$ & 13 & 43 \\
\hline 4 & Kegiatan sosial & 2 & 7 \\
\hline 5 & $\begin{array}{l}\text { Mengetahui cara } \\
\text { pengolahan rasi }\end{array}$ & 8 & 27 \\
\hline
\end{tabular}

Berdasarkan tabel diatas $43 \%$ responden datang ke Kampung Adat Cireundeu untuk mencoba rasi sebagai salah satu produk 
agroindustri dan mengenal Kampung Adat Cireundeu karena budaya yang informasinya sudah menyebar. Artinya, agrowisata di Kampung Adat Cireundeu akan menentukan nilai permintaan agroindustri singkong setempat dan agrowisata merupakan sarana pemasaran dan promosi produk tersebut.

\section{2) WTP}

Analisis ini digunakan untuk mengetahui harga yang dapat dikeluarkan oleh pengunjung dengan cara membuat hipotesis pasar sendiri. Hipotesis pasar yang ditawarkan dalam analisis ini ialah pengunjung diperkenalkan dengan budaya lokal yang ada di Kampung Adat Cireundeu. Pengunjung diajak melihat keindahan alam ke Puncak Salam dan Bukit Gajah Langu, kemudian diperlihatkan tentang aplikasi penggunaan tata lahan yang digunakan, mendapatkan simulasi cara pembuatan rasi, dan diajak mencoba mengkonsumsi rasi seperti masyarakat adat Cireundeu. Hal tersebut merupakan keadaan pasar yang ditawarkan kepada pengunjung agar dapat diketahui keinginan membayar pengunjung dengan fasilitas dan produk yang ditawarkan. Berikut ini hasil analisis Willingness to Pay yang disajikan pada Tabel 10.

Tabel 10. Hasil analisis WTP

\begin{tabular}{crrrr}
\hline No. & $\begin{array}{c}\text { Harga } \\
\text { Tiket } \\
\text { (Rp.) }\end{array}$ & $\begin{array}{c}\text { (\%) } \\
\text { Harga }\end{array}$ & $\begin{array}{c}\text { Hasi } \\
\text { (Rp.) }\end{array}$ \\
\hline 1 & 5.000 & 6,7 & 3.000 & 3,3 \\
\hline 2 & 10.000 & 23,3 & 4.000 & 6,7 \\
\hline 3 & 15.000 & 13,3 & 5.000 & 13,3 \\
\hline 4 & 20.000 & 23,3 & 6.000 & 3,3 \\
\hline 5 & 25.000 & 13,3 & 9.000 & 3,3 \\
\hline 6 & 30.000 & 13,3 & 10.000 & 50,0 \\
\hline 7 & 40.000 & 3,3 & 15.000 & 6,7 \\
\hline 8 & 50.000 & 3,3 & 25.000 & 3,3 \\
\hline 9 & & & 30.000 & 6,7 \\
\hline 10 & & & 40.000 & 3,3 \\
\hline Rataan & $\mathbf{1 9 . 6 6 7}$ & & $\mathbf{1 1 . 7 0 0}$ & \\
\hline
\end{tabular}

\begin{tabular}{lll}
\hline Median & $\mathbf{2 0 . 0 0 0}$ & $\mathbf{1 0 . 0 0 0}$
\end{tabular}

Harga tersebut didapatkan dari masingmasing median harga tiket dan harga rasi karena rentang harga jauh. Adapun persentasi paling tinggi masing-masing untuk tiket sebesar 23\% dengan harga Rp.20.000,00 sedangkan untuk rasi 50\% dengan harga Rp.10.000,00. Artinya kedua harga tersebut merupakan harga yang paling cocok dengan kemampuan pengujung karena harga tersebut yang paling sesuai dengan kualitas yang diberikan produsen berdasaran persepsi pengunjung.

\section{3) IFE \& EFE}

Berdasarkan hasil analisis faktor internal perusahaan menunjukkan keadaan internal perusahaan kuat yang diketahui dari total skor pembobotan sebesar 2,11. Skor tersebut menunjukan nilai $<2,5$ yang artinya keadaan internal Kampung Adat Cireundeu lemah, sedangkan hasil analisis faktor eksternal perusahaan menunjukkan keadaan eksternal perusahaan kuat yang diketahui dari total skor pembobotan sebesar 2,70. Skor tersebut menunjukan nilai $>2,5$ yang artinya perubahan lingkungan direspon dengan baik oleh Kampung Adat Cireundeu.

\section{4) SWOT}

Berdasarkan hasil analisis persepsi pengunjung, willingness to pay, lingkungan internal dan eksternal Kampung Adat Cireundeu yang telah dilakukan maka dapat ditentukan kekuatan, kelemahan, peluang, dan ancaman. Dengan analisis SWOT, perusahaan diharapkan dapat menyusun strategi bersaing berdasarkan perpaduan fakto-faktor internal dan eksternal tersebut. Strategi dalam meningkatkan daya saing produk berdasarkan analisis SWOT dilakukan melalui empat strategi yaitu strategi S-O, strategi W-O, strategi S-T dan strategi W-T. 
Euis Dasipah, I. Iskandar, dan Rimelke R. Febryane: Kajian Pengembangan Agribisnis Singkong (Manihot Esculenta) Berbasis Kearifan Lokal Melalui Penerapan Agrowisata Di Kampung Cireundeu

\begin{tabular}{|c|c|c|}
\hline Internal & Strengths (S) & Weaknesses (W) \\
\hline Eksternal & $\begin{array}{l}\text { 1. Ketersediaan sumber daya manusia } \\
\text { yang kompeten } \\
\text { 2. Ketersediaan lahan dan bahan baku } \\
\text { yang melimpah } \\
\text { 3. Harga sarana produksi yang rendah } \\
\text { 4. Kualitas produk rasi dan olahan } \\
\text { singkong lainnya yang menyehatkan } \\
\text { dibandingkan olahan tepung beras } \\
\text { 5. Harga jual murah }\end{array}$ & $\begin{array}{l}\text { 1. Promosi terbatas } \\
\text { 2. Sumber modal terbatas } \\
\text { 3. Penerapan teknologi yang } \\
\text { memerlukan proses cukup panjang } \\
\text { agar diterima masyarakat } \\
\text { 4. Saluran pemasaran belum banyak } \\
\text { 5. Pemahaman tentang organisasi } \\
\text { yang masih rendah bagi para } \\
\text { pengurus khususnya KWT } \\
\text { (pengelola agroindustri) }\end{array}$ \\
\hline
\end{tabular}

\section{Opportunitiess (O)}

1. Nilai budaya lokal yang tinggi menjadi nilai ekonomi yang ditawarkan

2. Belum ada esaing yang memproduksi rasi khususnya di Jawa Barat dan aneka olahan singkong hingga ke kulitnya

3. Pelayanan pengelola yang ramah

4. Hubungan konsumen yang selalu terjalin dengan baik

\section{Strategi S-O}

1. Meningkatkan kualitas sumber daya manusia dalam memberikan pelayanan kepada pengunjung dan melakukan proses produksi, promosi, dan penjualan dengan agar citra pengembangan agribisnis singkong baik.

2. Memanfaatkan harga sarana produksi yang rendah dengan terus memperkenalkan budaya lokal tidak makan nasi.

3. Menciptakan kualitas produk yang lebih beragam dari segi varian untuk beberapa produk agar daat bersaing dipasar.

Strategi W-O

1. Memperkenalkan produk melalui media brosur yang diberikan kepada konsumen yang pernah datang agar dapat memberi rekomendasi kepada orang lain, serta lebih gencar menggunakan pemasaran online dengan setiap pengantaran pemesanan konsumen diberikan materi perkenalan mengenai budaya Cirundeu.

2. Mendirikan restoran yang bernuansa Kampung Adat Cireundeu.

3. Memperluas saluran pemasaran agar jaringan hubungan konsumen semakin luas, mengingat sumber daya manusia bisa yang banyak dan cukup kompeten.

Threats (T)

Strategi S-T

Strategi W-T

1. Perubahan selera konsumen yang mengikuti life style

2. Keindahan alam dan fasilitas yang dimiliki menjadi rusak

3. Kebijakan pemerintah yang menghambat pengembangan agroindustri dan agrowisata

4. Aksesbilitas konsumen yang terbatas
1. Pemerintah mengadakan pelatihan untuk meningkatkan kemampuan produksi, pemasaran, dan ekonomi kreatif masyarakat agar tercipta produk-produk yang lebih beragam.

2. Kerjasama pemerintah dalam melakukan pembangunan wahana rekreasi pengunjung untuk meningkatkan nilai ekonomi.
1. Menerima bantuan pemerintah berupa mesin pembuatan rasi kombinasi sehingga tercipta produk rasi dengan inovasi dan mengikuti ajakan-ajakan kunjungan ke agrowisata lain agar referensi konsep agrowisata bertambah.

2. Peningkatan kemampuan berorganisasi dan birokrasi dalam pengelola lebih fleksibel dalam menjalankan pengembangan agribisnis singkong.

\section{Gambar 4. Matriks SWOT Strategi Pengembangan Agribisnis Singkong Cireundeu}


Menurut hasil analisis Internal dan External Factor Evaluation, pada faktor internal yang memiliki nilai lebih tinggi adalah kelemahan (weeknesess) sebesar 1,1 sedangkan pada faktor eksternal yang dominan adalah peluang (opportunity) sebesar 1,4. Kedua angka tersebut menentukan posisi kuadran strategi seperti dibawah ini:

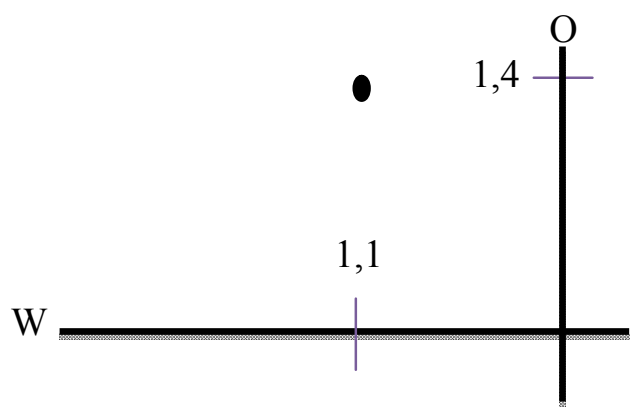

Gambar 8. Kuadran SWOT

Kedua nilai tersebut menggambarkan posisi Kampung Adat Cireundeu terhadap posisi strategi yang perlu dilaksanakan. Posisi tersebut ada pada kuadran 3 artinya pengelola Kampung Adat Cireundeu perlu melakukan diversifikasi strategi dengan mengandalkan kelemahan yang dimiliki menjadi kekuatan dalam menghadapi peluang. Strategi W-O merupakan strategi yang paling tepat diterapkan pada pengembangan agribisnis singkong di Kampung Adat Cireundeu.

\section{KESIMPULAN}

Berdasarkan hasil penelitian dan pembahasan, maka dapat ditarik kesimpulan sebagai berikut :

1. Berdasarkan analisis deskriptif persepsi pengunjung diketahui bahwa terdapat keterkaitan diantara agroindustri singkong dengan agrowisata di Kampung Adat Cireundeu, 43\% responden mengakui alasan kunjungan merek untuk mencoba rasi dan mempelajari budaya setempat dan $60 \%$ responden juga memiliki minat untuk membeli produk olahan singkong lainnya. Selain itu, tingkat kepuasan pengunjung baik ditunjukan dengan hasil analisis kuantitatif terhadap persepsi pengunjung sebesar 3,21 dan pengunjung ingin membayar tiket dengan harga Rp.20.000,00 dan rasi sebesar Rp.10.000,00 per kg berdasarkan hasil analisis willingness to pay.

2. Strategi pengembangan agribisnis yang tepat dilakukan Kampung Adat Cireundeu dalam penerapan agroindustri dan agrowisata berdasarkan analisis SWOT yaitu diversifikasi strategi karena posisi strategi paling baik pada kuadran 2 (Strategi W-O).

\section{DAFTAR PUSTAKA}

Asmiawati, Mia. (2016). Studi tentang Penataan Ruang Kawasan Pedesaan di Kecamatan Muara Ancalong Kabupaten Kutai Timur (Studi Kasus di Desa Kelinjau Ulu). e-Journal Ilmu Pemerintahan, 4 (4), hlm. 1855-1866 ISSN: $\quad 2477-2458 . \quad$ Samarinda: Universitas

Mulawarman.http://ejournal.ip.fisipunmul.ac.id. Diakses pada 22 Februari 2017.

Basuki, Sulistyo. (2010). Metode Penelitian. Jakarta : Penaku.

BKPPP Bantul. (2014). Data Kandungan Gizi Bahan Pangan dan Olahan. [Online]. Diakses dari www.bkppp.bantulkab.go.id. Pada November 2016

Creswell, John W. (2009). "Research Design Qualitative, Quantitave, and Mixed Methods Approacher". California: Sage Publication Inc

David, F.R. (2006). Manajemen Strategis. Edisi 10 Buku 1. Jakarta: Salemba Empat.

David, F.R. (2008). Strategic Management: Manajemen Strategi Konsep Edisi 10. Jakarta: Salemba Empat.

David, F.R. (2010). Manajemen Strategis. Jakarta: Salemba Empat.

Fauzi, A. (2006). Ekonomi Sumberdaya Alam dan Lingkungan. Jakarta: Gramedia Pustaka Utama. 
Euis Dasipah, I. Iskandar, dan Rimelke R. Febryane: Kajian Pengembangan Agribisnis Singkong (Manihot Esculenta) Berbasis Kearifan Lokal Melalui Penerapan Agrowisata Di Kampung Cireundeu

Handoko, T. Hani. (1999). Manajemen. Yogyakarta: BPFE Yogyakarta.

Judistira K. G. (2008). Budaya Sunda: Melintas Waktu Menentang Masa Depan. Bandung: Lemlit UNPAD.

Kotler, Philip. (1997). Manajemen Pemasaran. Jakarta: Prenhallindo.

Nazir, Mohammad. (1988). "Metode Penelitian". Jakarta: Ghalia Indonesia.

Pearce dan Robinson. (1997). Manajemen Strategis. Jakarta : Binarupa Aksara.
Rangkuti, Freddy. (2008). "Analisis SWOT Teknik Membedah Kasus Bisnis". Jakarta: PT. Gramedia Pustaka Utama. Serikat Petani Indonesia. (n.d). Kedaulatan Pangan.[Online]. Diakses dari www.spi.or.id. Pada November 2016.

Sjarkowi, F. dan M. Sufri. (2004). Manajemen Agribisnis. Palembang: CV. Baldal Grafiti Press. 2016. Konsumsi Beras Perkapita Indonesia. [Online]. Diakses dari www.databoks.katadata.com. Pada November 2016. 